\title{
A life for surgery: Julius Kraft-Kinz
}

\section{December 13, 1925, Innsbruck, Austria-May 31, 2018, Graz, Austria}

\author{
Hans-Jörg Mischinger
}

(C) Springer-Verlag GmbH Austria, part of Springer Nature 2018

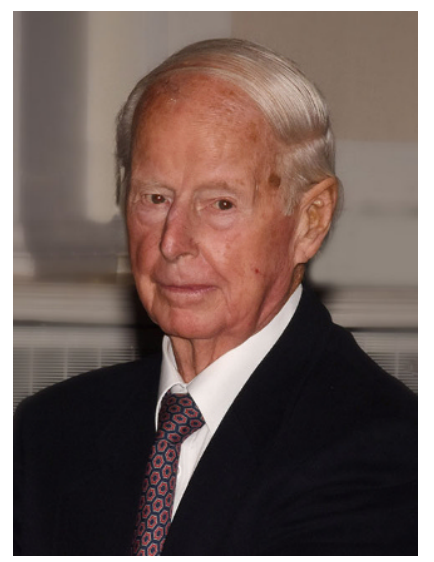

em. Univ.-Prof. Dr. Dr. hc. Julius Kraft-Kinz. (๑ Klinikarchiv MedUniGraz)

Julius Kraft-Kinz was born on December 13, 1925 in Innsbruck, Austria. Shortly after beginning medical school in 1944, he was drafted and served in the military until the end of the war, when he resumed his medical studies and received his M.D. in 1951 from the University of Innsbruck. After two years' residency in pathology here, he went on to the Rhineland to work with his uncle, Rudolf Kraft, chief of surgery in Düren. After further training in surgery at the University Hospital in Munich, he took a position at the University Department of Surgery in Graz under Franz Spath in 1956.

It was in Graz that he came into his own as a surgeon, realizing his ambitions in cardiovascular and thoracic surgery in clinical practice and research. His

o. Univ.-Prof. Dr. H.-J. Mischinger ( $ه)$

Department of Surgery, Chair of Surgery, Medical University of Graz, Auenbruggerplatz 5, 8036 Graz, Austria

hans.mischinger@medunigraz.at

work on vascular grafts and techniques for freezedrying of biological materials led to the establishment in Graz of the first biobank for homologous vascular grafts and laid the groundwork for his postdoctoral thesis on obliterative arterial disease, which was accepted in 1964. With that accomplishment, he achieved the rank of University Lecturer and Deputy Head of Surgery.

In 1962, close cooperation with Rudolf Zenker in Munich laid the groundwork for open-heart surgery with the heart-lung machine. Postdoctoral fellowships had also taken him to major heart centers in the United States, including Harvard, and to Aldo Castaneda, the distinguished pediatric heart surgeon.

With this background, on September 19, 1962, he was able to play a major role in the first open-heart operation in Austria, together with Franz Spath and two specialists from Germany. With the heart-lung machine, congenital heart defects in children could also be corrected, and again it was in Graz that the first operation in Austria to correct a tetralogy of Fallot was performed. That patient, incidentally, is still alive and well.

The next obvious step was heart transplantation. In animal studies, the heart transplant team in Graz had perfected the technical aspects of the operation by 1962, but the problem of rejection of foreign tissue had not yet been solved. Nothing better exemplifies Kraft-Kinz's integrity and high ethical standards than his refusal at the time to rush to perform a procedure when he could not be reasonably sure of its success and the wellbeing of the patient. Thus, it was only in 1984 that Kraft-Kinz felt that all the prerequisites were in place, and he and his team performed the first heart transplant it Graz.

In 1970, just after his 45th birthday, Kraft-Kinz succeeded Franz Spath as Chair of Surgery in Graz, heading a single mammoth department with 36 doctors 


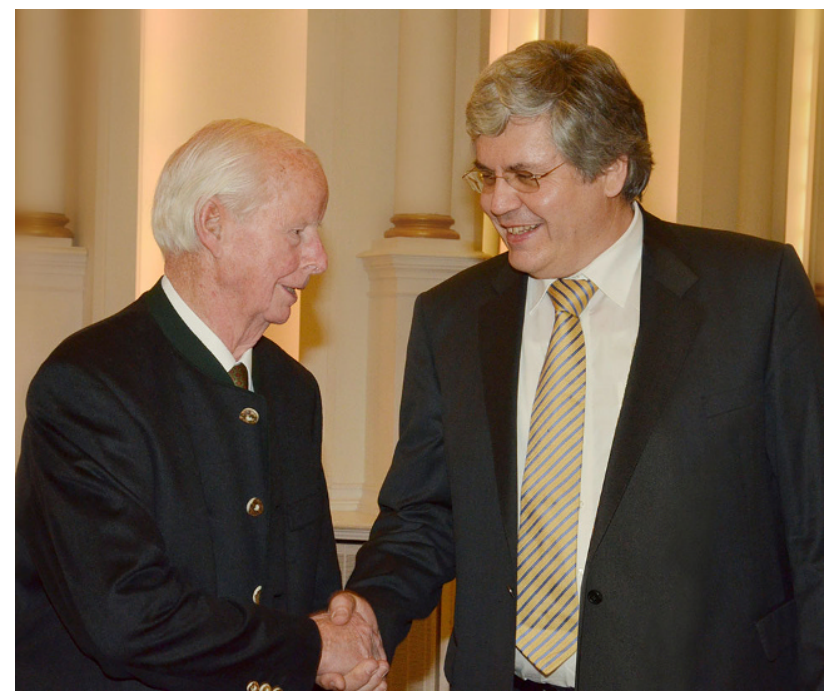

Prof. Mischinger congratulates Prof. Kraft-Kinz on the occasion of his $90^{\text {th }}$ birthday at the Annual Meeting of the University Department of Surgery in 2015. (C Klinikarchiv MedUniGraz)

and 400 beds. He immediately set about achieving his vision of a more efficient service, restructured and reorganized along the lines of the American system, with a department comprising a number of semi-autonomous divisions. This involved complicated negotiations with the numerous bodies involved, but in 1971, his concept was approved. This system has in the meantime been adopted by university hospitals throughout Austria.

It had also become clear to Kraft-Kinz that training in surgery needed to be rethought. Surgical residents in urology, trauma surgery, and orthopedics would no longer first have to become certified in general surgery before beginning their training in those disciplines that were now specialties in their own right. Along the same lines, a professorship for transplantation surgery was established in 1986.

For more than 40 years, Kraft-Kinz was an active and influential member of the Austrian Surgical Association, serving as its president and organizing annual meetings when they were held in Graz. The association served him as a platform to promote his principles and visions, which even today are still highly relevant for clinical practice, research, and training in surgery.

Owing to his many pioneering academic publications and professional charisma, he was awarded many prizes and honors, including an honorary doctorate, honorary memberships in professional societies, the highest decoration awarded by the Styrian Government, the Grand Gold Medal of Honor with Star, and the Auenbrugger Honor Cross of the Medical University of Graz. He always received such distinctions with reticence and modesty.

As Chairman of Surgery for 26 years, Kraft-Kinz not only guided his department successfully through a period of major administrative and clinical changes, he shaped generations of surgeons, not only honing their technical skills but also instilling in them his high ethical and moral principles, first and foremost the injunction "nihil nocere," to do no harm. Many of the residents whose training in surgery he oversaw have gone on to leading positions in major hospitals. His students and colleagues will remember Julius Kraft-Kinz fondly as an academic surgeon, a paragon, a mentor, and a friend.

Throughout his long and productive career, and thereafter as Professor emeritus of Surgery, Kraft-Kinz drew his strength from a supportive and loving family, from classical music, and from the mountains in his native Tyrol. 